\title{
Design Information System Stock Inventory To Manage Data Of Goods (Case Study: PT Monier)
}

Author Notification 4 August 2019

Final Revised

1 November 2019

Published

26 December 2019
To cite this document:

Supriyanti, D., Kesumawati, C., \& Maryam, S. (2019). Design Information System Stock Inventory To Manage Data Of Goods (Case Study: PT Monier). Aptisi Transactions On Management (ATM), $4(1), 22-31$.

DOI:

http://ijc.ilearning.co/index.php/ATM/article/view/1081

\begin{abstract}
Application of information system on the inventory will provide many benefits for the company in developing company in order to improve the company's performance become more effective and efficient. This research was conducted at manufacturing companies, to know overall about inventory items in the company. The purpose of this research is to find out the effectiveness of the inventory as a resource physical economy that needs to be held and maintained in order to support the process booking goods and sales in progress PT Monier. PT Monier is as a company manufacturers concrete roofing materials with the production system where the process for creating objects with cross-section of fixed. The methods of analysis used is descriptive data analysis method. Engineering data collection with do the observations to the company, conducting interviews, and route the study library with books, the literary, the materials gained during lectures relevant to the problems examined. Research results shows that the control of inventory items It often happens booking of the goods to the supplier in excess inventory and the shortage of supplies. Due to the lack of regard for the State of inventory items. Inventory data input errors often occur more than once for similar goods give rise to errors in reporting. Then the author here attempted to analyze the problems against information systems inventory items and to find solutions to the fore of the existing problems by fixing a system that is less than optimal.
\end{abstract}

Keywords: Information Systems, Effectiveness, Inventory Items

\section{Introduction}

In entering the wider world of economic development today, every growing and growing company requires an internal control of good inventory in support and facilitate its production activities. The company's main objective is to gain optimal profit in accordance with the company's growth in the long term, so as to ensure the company's survival.

Inventories are the most active element in the trading company and one of the basic requirements that must be fulfilled and owned by a company in the trade activity because in trading traded is the inventory. In the enterprise, there is a stock of goods that handle the process of order goods or sales. In relation to the supply of goods and the return of an item that should be processed so that the data can be easily accessed.

Inventories are vulnerable to damage and theft. Damage, incorrect insertion, negligent to record the request, the goods issued are not on order, and all other possibilities may cause the inventory record to differ from the actual inventory there is in the warehouse. For that it takes internal control of the supplies aimed at protecting the company's property and also for the information on inventories to be more trustworthy.

PT MONIER is located in Cikokol Tangerang. Potentially industrial area Jl. MH. Thamrin No. 24 Cikokol Operating since 1973, MONIER has a quality roof system solution consisting of 
concrete roof tile, accessories and roofing system components to keep the customer's quality of life increasing.

These things can be avoided, with a stock report of goods using a computerized system. With the existence of a computerized system in presenting information on complete goods inventory and can access data and information quickly in terms of data processing, efficient in terms of energy, accurate in terms of complete information and Easier to know the amount of inventory available in a warehouse.

\section{Research Method}

The research method of PT Monier is used to solve various problems that exist in this research. The data collection methods used, among others :

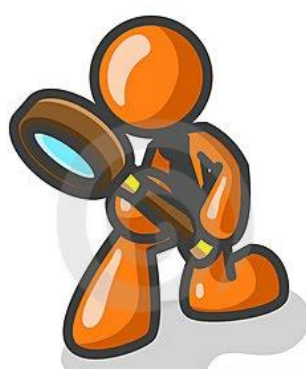

Observation

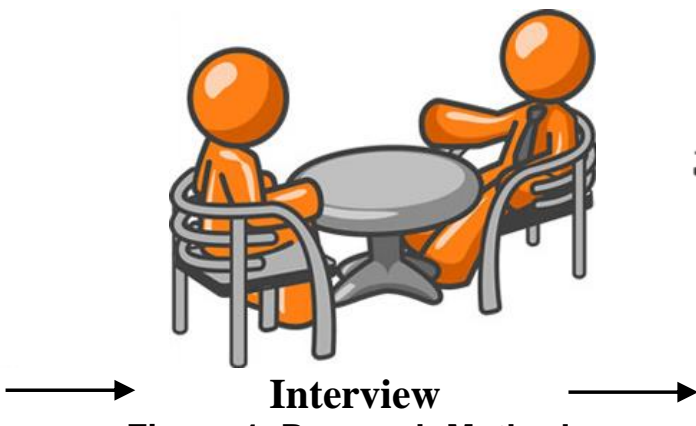

Figure 1. Research Methods

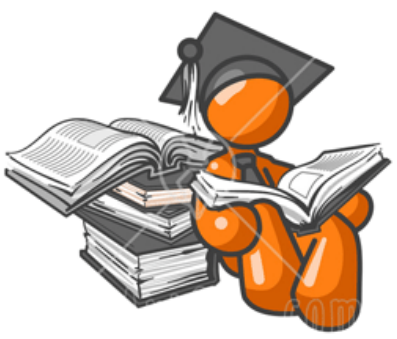

Library

1. Observation Research

First done, the researcher conducted a direct observation in the activity of work and do a systematic recording of the elements that are directly researched to the warehouse section of PT. MONIER which is addressed Cikokol Industrial Area, Tangerang 15117 in industrial field Concrete Roof Tiles, Accessories, Quality Roofing to get the necessary data in the research is being done.

2. Interview Reseacrh

Then the researcher began to conduct a direct question and answer session to those directly related to the warehouse system and the purchase to obtain the information data needed for the process of the straightness in this research. And researchers managed to obtain accurate and reliable information through Mr. Edi Susanto as Store Supervisor at PT. Monier.

3. Library Research

After the observation and interviews in detail then the utility to conduct the study of the library in which this library study was conducted to obtain information from several literature sources of review such as Internet, books, journals, and other Related research as reference material in the preparation of the final task.

The following is a list of literature reviews used in this study :

1. Research conducted by Anthony Anthony, Andeka Rocky Tanaamah, and Agustinus Fritz Wijaya of the Journal of Technology and Computer Science in the year 2017 titled "ANALYSIS AND DESIGN of SALES INFORMATION SYSTEM BASED ON WAREHOUSE-BASED STOCK CLIENT SERVER (WHOLESALE SHOP CASE STUDY "RESTU YOU"). Explained that the research they do especially on the sales system of goods that run your Restu store has not been computerized so that the sale of goods that do not run properly. Therefore, to solve the problem, the sales information system was built based on a client-server-based warehouse stock.

2. Research conducted by Muhammad Reza Putra from the technology journal in 2016 titled "ANALYSIS of SYSTEM DESIGN PREDICTION ORDERING AND CONTROLLING STOCK of GOODS USING EOQ METHOD". Explained that the research that they do on the database system in the production of stock report data takes a long time and very difficult in the search of data then researchers use the method of Economic Order Quantity (EOQ) EOQ model used to Determines the quantity of inventory orders that can minimize storage costs and inventory booking costs.

3. Research conducted by Fatmawati and Jajat Munajat from the journal Media Informatics Budidarma in the year 2018 titled "IMPLEMENTATION of MODEL WATERFALL on the SYSTEM of INFORMATION on the SUPPLY of GOODS BASED on WEB (CASE STUDY: PT. 
PAMINDO TIGA T)". Explained that the research they have done is about the results of analysis using SDLC method with waterfall model. The waterfall model has 5 stages so it can be easier to get the latest information, and facilitate the processing of incoming goods and outbound goods.

4. Research conducted by Ani Oktarini Sari and Elan Nuari from PILAR Nusa Mandiri Journal in 2017 entitled "DESIGN BUILD INFORMATION SYSTEM FOR WEB-BASED GOODS in the FAST METHOD (FRAMEWORK FOR THE APPLICATIONS)". Explained that the research they do is not the accuracy of data stock of goods. Therefore analyze the utilities using the system development model of FAST method (Framework for the Application System Thinking). Which is where the proposed system benefits can facilitate data retrieval and data processing to get out of the goods more effectively and efficiently.

5. The research conducted by Kusmanto from the INFOTEK scientific journal in 2018 titled "The APPLICATION PLANNING of RUBBER SAP SUPLAYER AT PT. RUBBER HOCK LIE USING VISUAL BASIC. NET ". Explained that the research they do in this part of the supplier is still using Microsoft Excel 2007. So that researchers designed the system by using Visual Basic Net because it is easy to understand and fast in its workmanship and facilities provided very much and the programs generated by the application is quite good quality and The use of the software is not very difficult.

6. Research conducted by Friska Baramuli and Sifrid S. Pangemanan from EMBA Journal in the year 2015 titled "ANALYSIS of INFORMATION SYSTEM ON INVENTORY ACCOUNTING for YAMAHA BIMA MOTOR TOLI TOLI". It is explained that the research that they are forming is the establishment of a must-have system owned by Yamaha Bima Motor Toli-Toli and the output received from a system which is the purpose of an accounting information system has been Appropriate, that is to change the existing information so that it becomes effective and efficient for all users information, as well as data generated with up-to-date assisting all parties in the presentation of inventory information and other information needed To make a decision.

7. Research conducted by Aris, Mochamad Rinja and Taufan Jherico. Technomedia Journal in the year 2017 titled "APPLICATION of MOTOR spare PARTS SALES ON WEB-BASED MOTORCYCLE WORKSHOPS". It was explained that the research they did on the system was designed using the OOAD method, and is illustrated through UML diagrams such as activity diagrams, sequence diagrams, use case diagrams, class diagrams and state chart diagrams. The system is built using the PHP programming language, and the database used is MySQL. The result of the design was a system of sales applications used to record every transaction that occurred and to make sales reports quickly and accurately. With the system, the user will be very helpful in working on his work.

\section{Results and Analysis}

\subsection{Problem Analysis}

Based on the analysis done, there are several problems encountered among them :

1. In the process of goods supply system in PT Monier has been done in semi-computerized, namely using Microsoft Excel, but not optimal because when it needs information on goods, Warehouse admins must open all existing tables and even check One by one the goods are available in the warehouse. So it is ineffective and efficient for warehouse admins because of the length of the data retrieval process resulting in a large amount of data that has been lost.

2. The preparation of incoming goods reports and outgoing goods at PT Monier still with the manual is write on paper by noting the date of entry or exit date, item code, quantity of goods and the other so as to make the admin warehouse difficulty to check the stock The inventory in the warehouse as well as the manual process resulted in the buildup of paper on the warehouse and ineffective overall.

3. Information about the goods in the warehouse is not maximized. Because there is often an error writing the Code of goods, the name of goods and also the quantity of goods, so that in controlling the order of goods results often the occurrence of excess or shortage of stock goods that fatal can make losses on Company.

\subsection{Troubleshooter}

Looking at the problems that often occur in PT Monier, then to overcome this need a workaround alternative is the first to design a system that is created from the creation of the UML diagram and prototype using the application Balsamiq so that can then make a computerized system Web-based for the inventory system, functioning to get information 
about the stock of goods updates so that the goods stock can be controlled well. By using a website the warehouse part no longer need to take notes on the paper for every logging of incoming goods and outgoing goods. The system is also able to provide update reports so as to minimize errors in the amount of goods per month so as not to make a loss on the company.

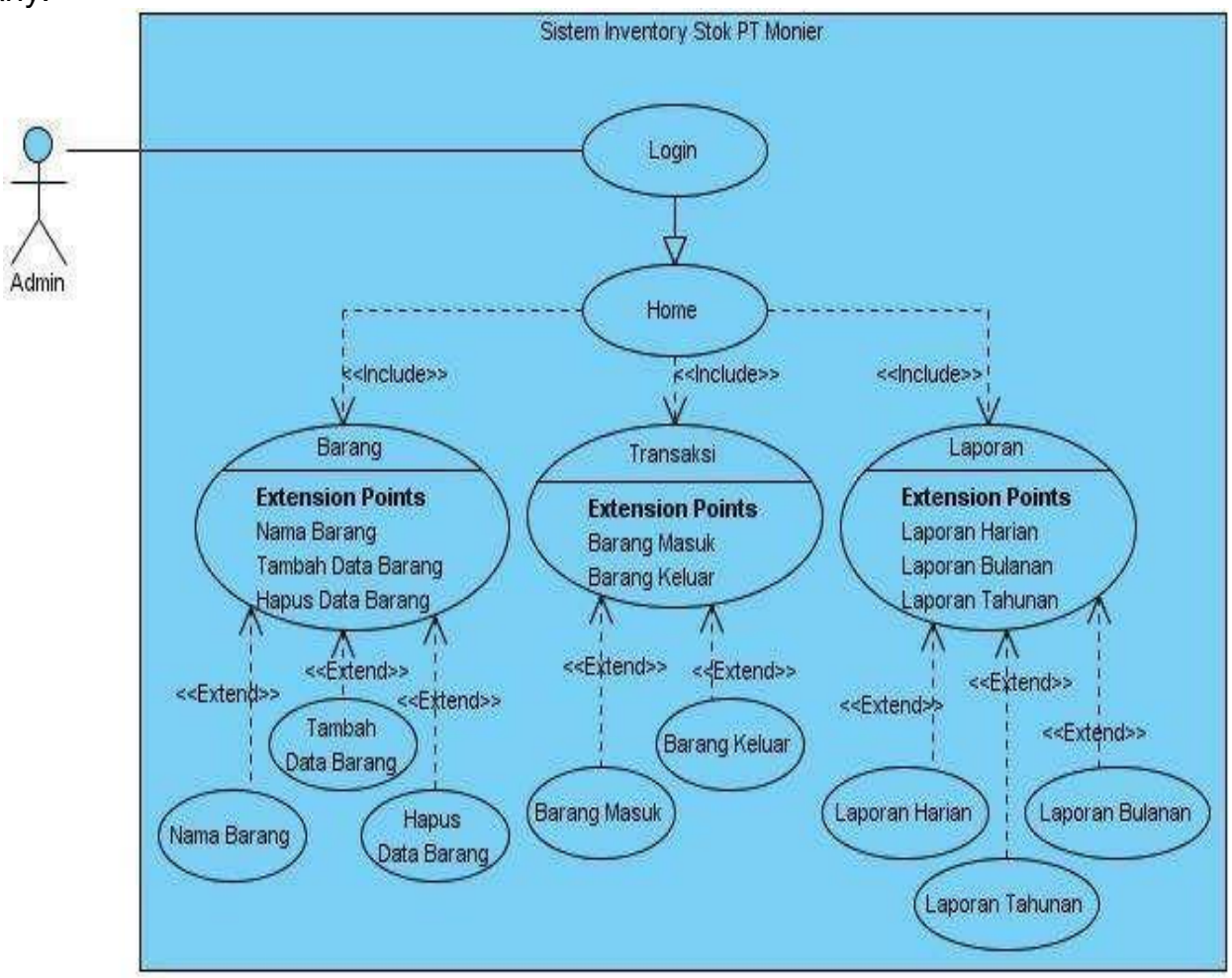

Figure 2. Usecase Diagram Admin Work Process

The explanation in the picture 2 above shows about the entire work process for admins who are functioning to record and display the stock data of the warehouse items as well as facilitate controlling the stock of existing goods in order to produce an accurate report. Where in the usecase it displays as a whole 1 (one) system that covers all the activities. In UseCase the author is made that there is 1 (one) actor who conducts the activity of data input goods is done by the admin, also there are 5 (five) usecase that can be done by actors namely login, home, goods, transactions, and reports. And besides, the system is also shown 3 (three) include goods, transactions, and also reports. Where in the system is also displayed 8 (eight) extends which includes the name of the goods, add the data of goods, delete the data of goods, incoming goods, outgoing goods, daily reports, monthly reports and annual reports.

\subsection{Program Listings}

Program listings are the arrangement of some data structures, then the arrangement can be compiled into a sort of programming command used in drafting a software command, which is used to design and build websites Invenory stock of goods at PT Monier. With the design of the website inventory stock goods can facilitate the admin part of the warehouse in the process of recording, input up to the manufacture of stock reports of goods for the company. And here is the program code used to create the website display of the stock inventory information system in PT Monier. 


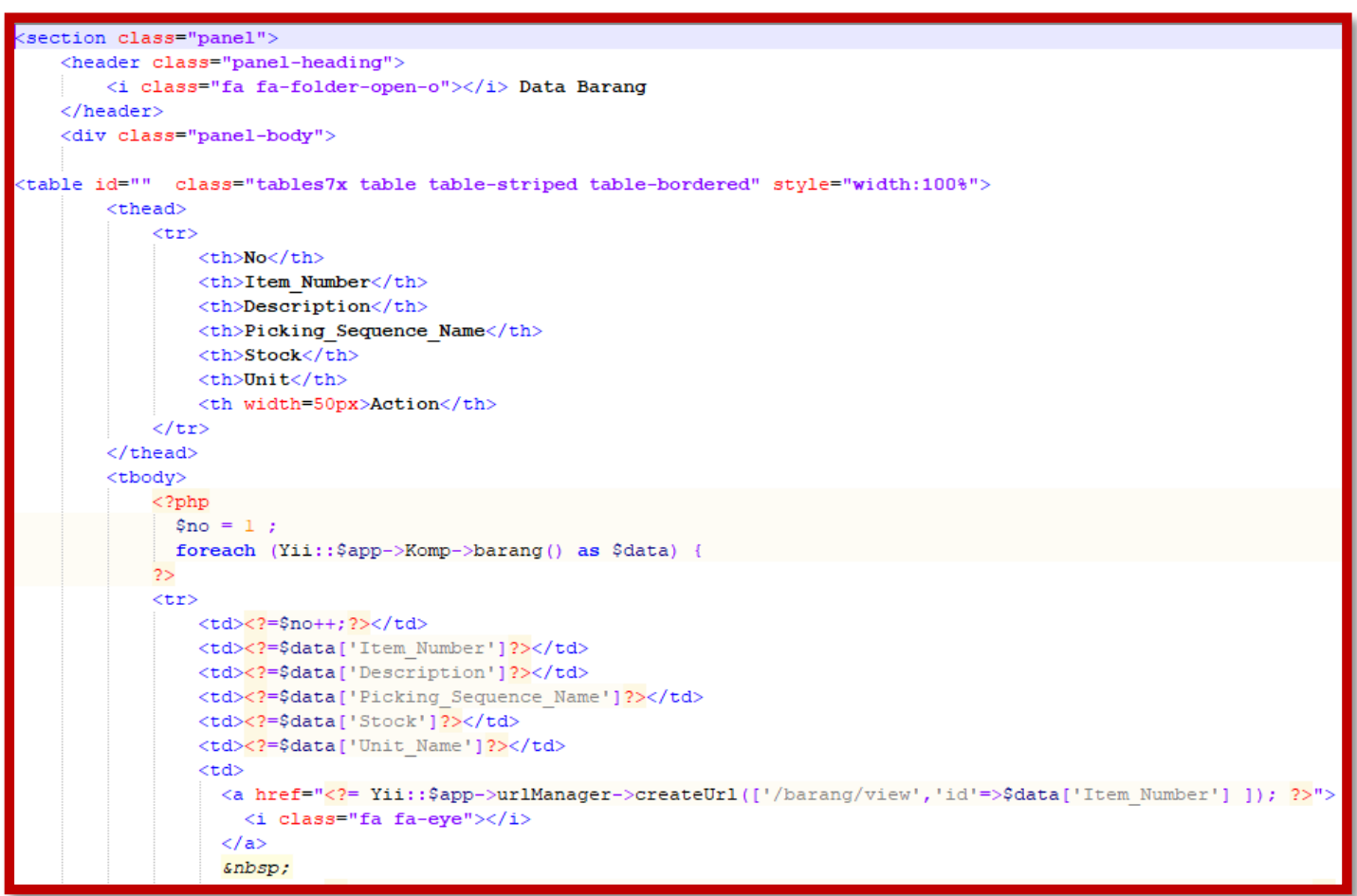

\subsection{Implementation}

From the results of the analysis can be made into a website display inventory system stock of goods to provide explanation of this web-based inventory system to do data collection and monitoring of the availability of goods Real time existing in PT Monier. as follows :

\section{Page Display Login}

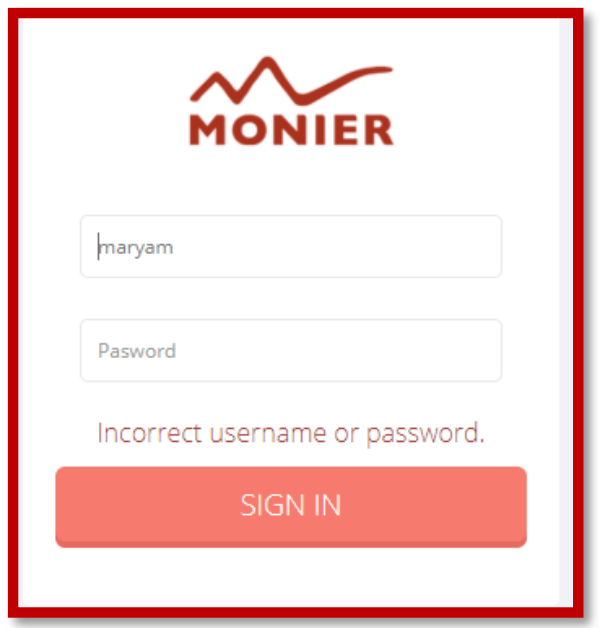

Figure 3. Page Display login

To be able to input the data of goods or others, which must be done first by the Admin warehouse is a warehouse admin can log in first to use the inventory system of goods by entering the username and password. Login can only be done by warehouse Admin with username and password already registered. After a successful login The warehouse admin can use the existing inventory system. 


\section{Display Dashboard}

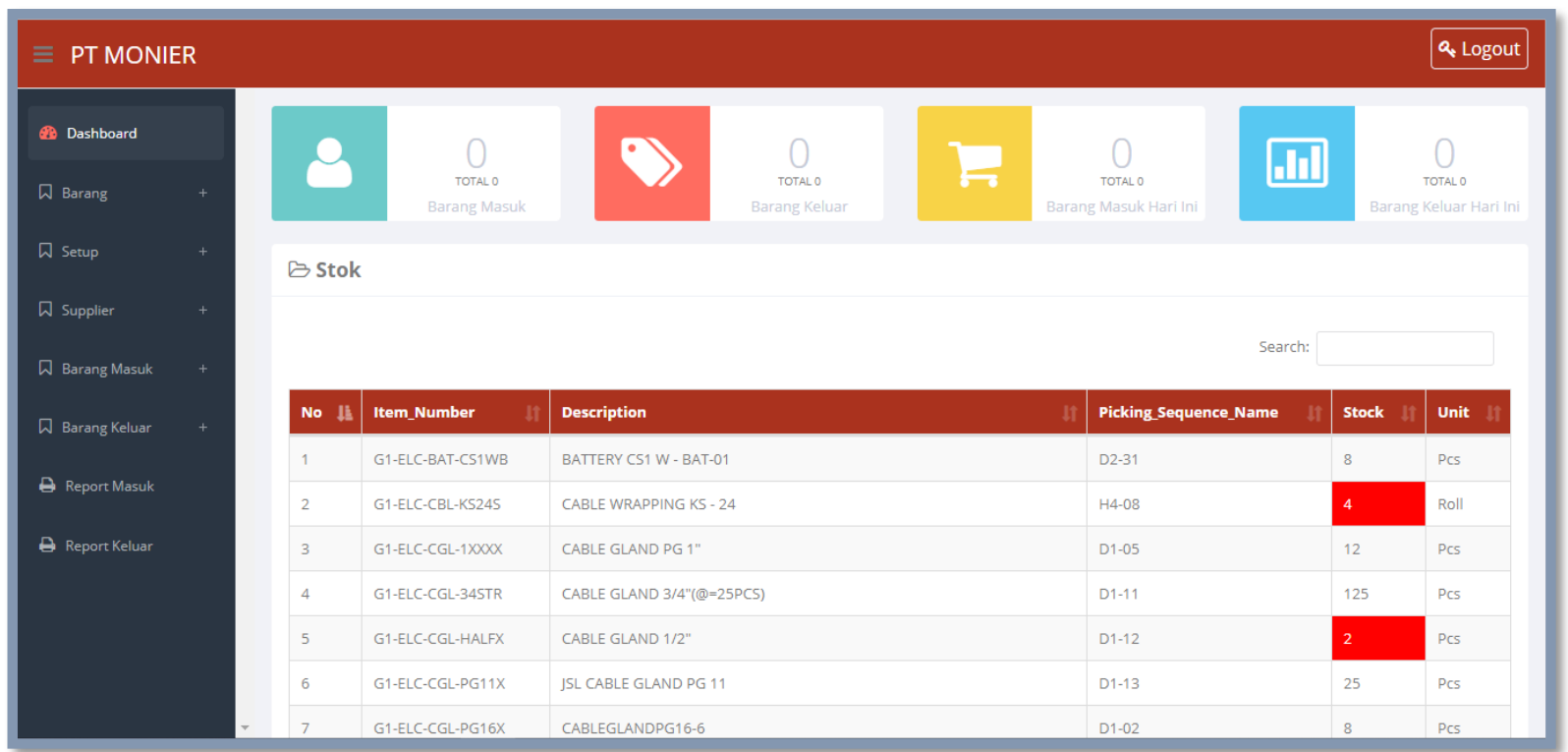

Figure 4. Display Dashboard

Once the warehouse admin is successfully logged in, the warehouse admin can see the dashboard view that fits the existing needs. In the dashboard view of spare parts on the system, this view of the warehouse admins can see the transactions made and can also see the stock of the remaining items in the warehouse. Where the stock of goods appearing in the dashboard will display a red Notif when the goods have reached the minimum stock.

\section{Display Data of Goods}

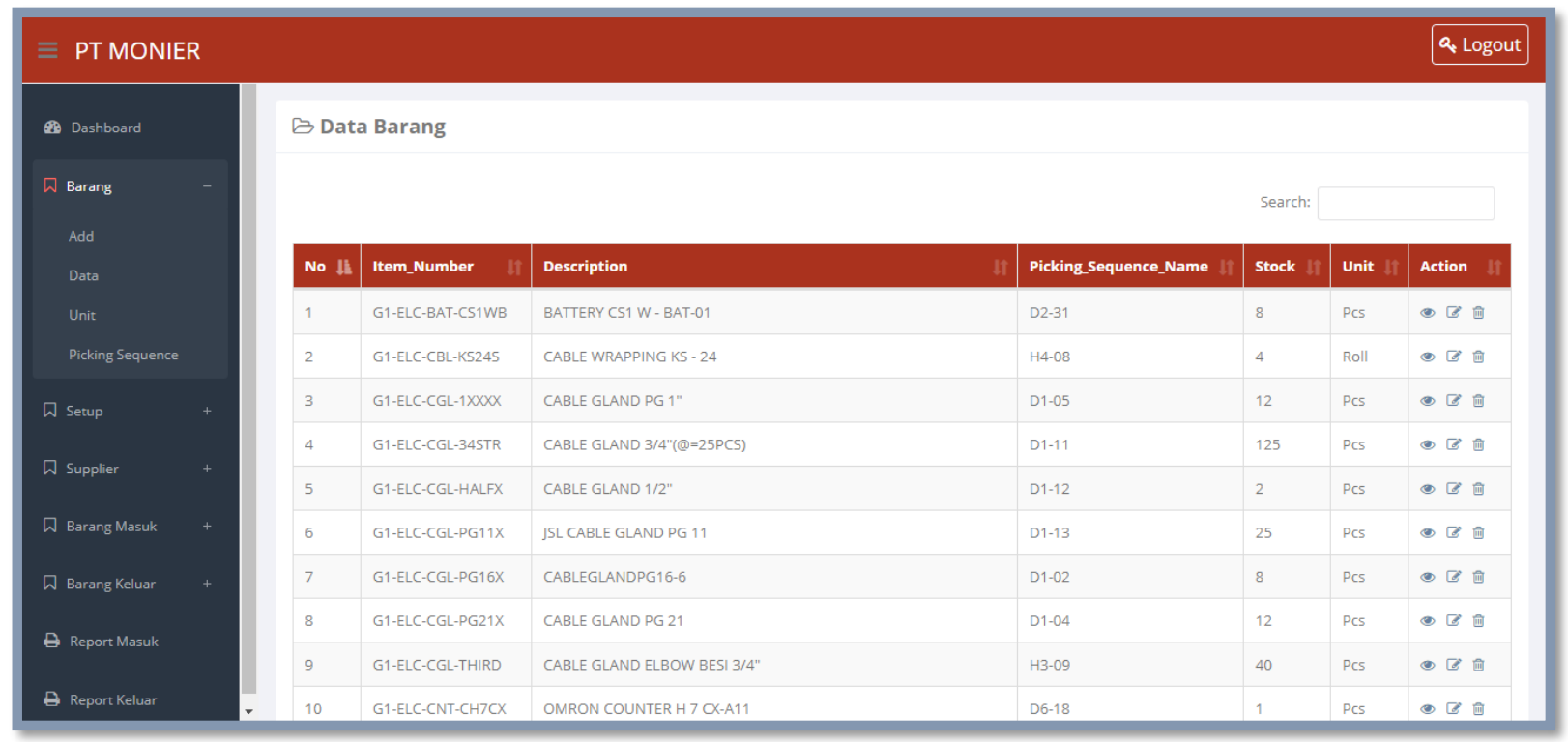

Figure 5. Display Data of Goods

Furthermore, Warehouse admins can view and input the goods data as needed. In the Data menu display item Sparepart on this system, this view of warehouse admins can input item number, description, picking sequence, stock, and units. Where to input the data Sparepart and also displays the results of all the data that has been entered. 


\section{Display Supplier Data}

\begin{tabular}{|c|c|c|c|c|c|c|c|c|}
\hline \multicolumn{8}{|c|}{$=$ PT MONIER } & Q. Logout \\
\hline \multicolumn{3}{|c|}{ 28 Dashboard } & \multicolumn{6}{|c|}{ Data Supplier } \\
\hline \multicolumn{2}{|c|}{ ఐ Barang } & + & \multicolumn{6}{|c|}{ Search: } \\
\hline \multirow{2}{*}{\multicolumn{2}{|c|}{ Ф Setup }} & + & No & Nam? & Pemilik it & Alamet & & \\
\hline & & & No il & Nama & Peminik और & Alamat & Kontak & Action if \\
\hline & Supplier & - & 1 & Asia Safety Indonesia, PT. & - & Jl. Angkasa Kota Baru Bandar Kem Kav B-6 Gunung Sa & (021) 26646768 & - 8 圆 \\
\hline & Add & & 2 & Mitra Sari CV & & Jl. Raya Centex No.29, RT.7/RW.3, Ciracas, Kec. Ci & (021) 8719238 & - 口回 \\
\hline & Data & & 3 & Lautan Ban & & Jl. Gatot Soebroto No.28, Uwung Jaya, Kec. Cibodas & (021) 5588099 & - 原回 \\
\hline \multicolumn{2}{|c|}{ ๑ Barang Masuk } & + & 4 & Mitra Cipta Hardi Elektrindo, PT. & & Jl. Mangga Dua Raya, RT.17/RW.11, Mangga Dua Sel., & (021) 6121212 & - 厚 囬 \\
\hline \multirow{2}{*}{\multicolumn{2}{|c|}{ W Barang Keluar }} & \multirow{2}{*}{+} & 5 & Nagamas Cahaya Sentosa / Bengkel Mesin "KING'S" & & & & - 厚 面 \\
\hline & & & 6 & Sinar Gas CV & & Jl. KH Hasyim Ashari, Km. 7, No. 108-B, Poris Pela & (021) 5520565 & - 原面 \\
\hline \multicolumn{2}{|c|}{ A Report Masuk } & & 7 & Naufal Prima Mandiri, PT. & & Ruko Taman, Kedaleman, Cibeber, Cilegon City, Bant & (0254) 7815008 & - 厚 回 \\
\hline \multirow{3}{*}{\multicolumn{2}{|c|}{ A Report Keluar }} & & 8 & P\&CBRUSHES & & & & - 6 皿 \\
\hline & & & 9 & Pratama Abadi Sentosa, CV. & - & Jl. Raya Serpong No.KM.7, Pakualam, Kec, Serpong U & (021) 5396140 & - 速田 \\
\hline & & & 10 & PT. Teman Sejati Sejahtera & & & (021) 89522075 & (-) 厚面 \\
\hline
\end{tabular}

Figure 6. Display Supplier Data

Furthermore, warehouse admins can see and input the supplier data as needed. On the Supplier menu display on the system, this view of the Warehouse admins can input names, owners, addresses, and contacts. Where to simplify the warehouse admin to input the supplier data and also display the results of all the data that has been in the inputs.

\section{Display Incoming Goods}

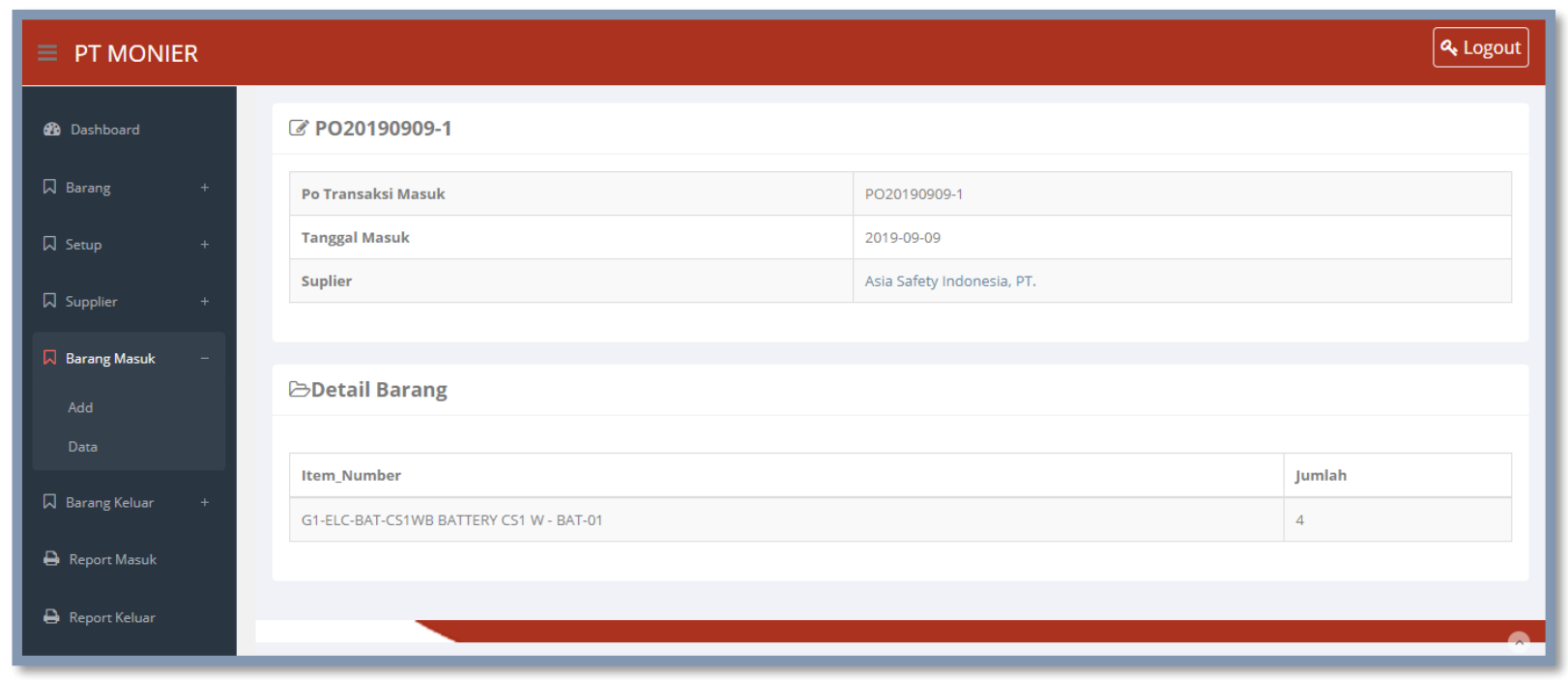

Figure 7. Display Incoming Goods

If there is an incoming goods warehouse admin directly can input the data of the goods in the system so as not to be buried goods in the warehouse that resulted in the buildup of goods warehouse. In the display of the incoming Goods Data menu on this system view the Admin warehouse can input the transaction, date of entry, supplier, item number, description and the amount of which will input the incoming goods data and also store the results of all data has been input. 


\section{Display Goods Out}

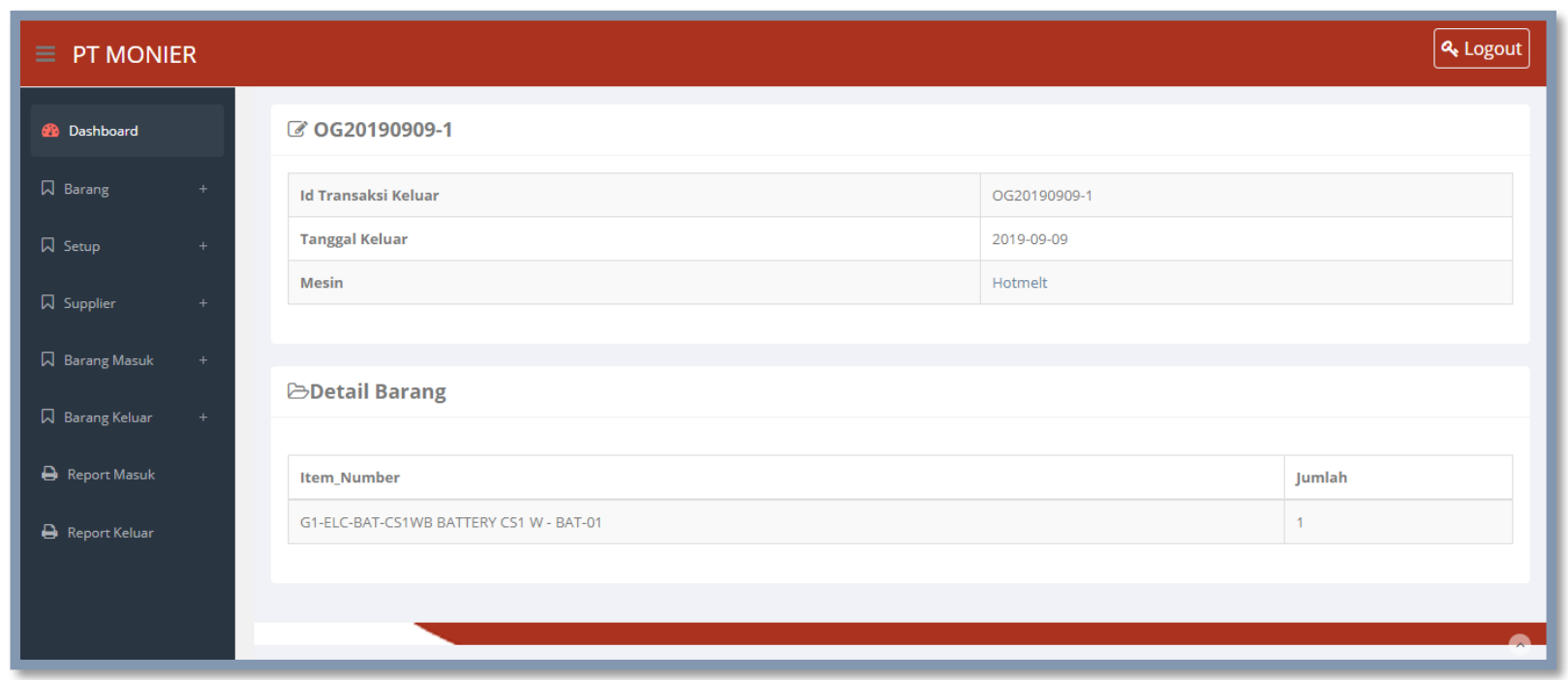

Figure 8. Display Goods Out

Goods to be used for production machinery needs should be recorded in the process of logging the goods out. In the display of Data menu item out on this system the display for the Warehouse admin can input PO outgoing transactions, outgoing date, machine, item number, and the amount where the result of the data Ginputan this outgoing goods can store the results of all data has been input.

\section{Display Incoming Goods Report}

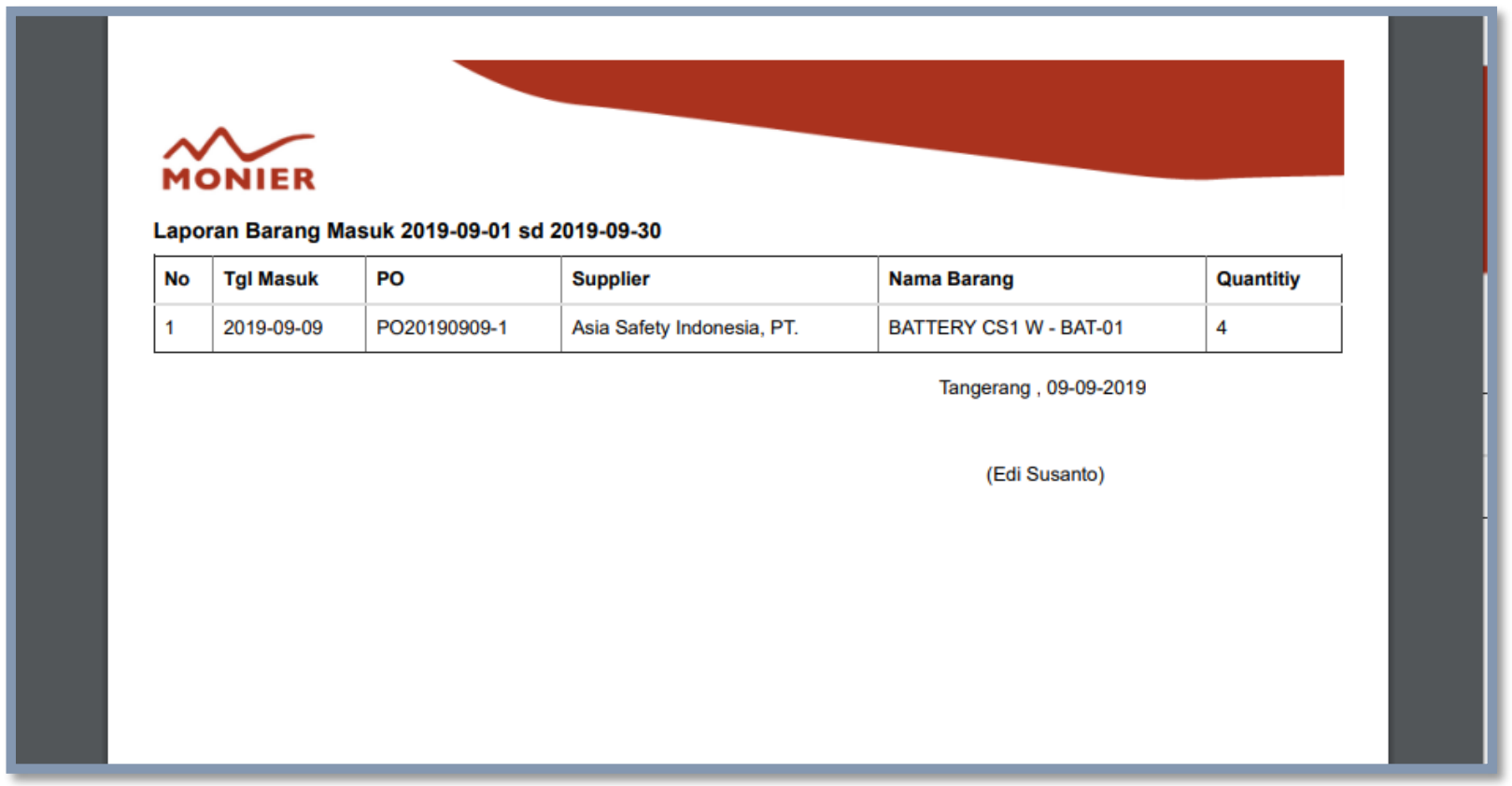

Figure 9. Display Incoming Goods Report

Once the admin of the warehouse makes the goods transaction in the Admin warehouse can see the report data on existing incoming goods every day, monthly and yearly. In the Data menu display of incoming goods reports on the system, this view of the 
warehouse admins can see in detail what there is on the incoming goods so as not to make a mistake in the number of incoming goods and make the data more accurate.

\section{Display Outgoing Goods Report}

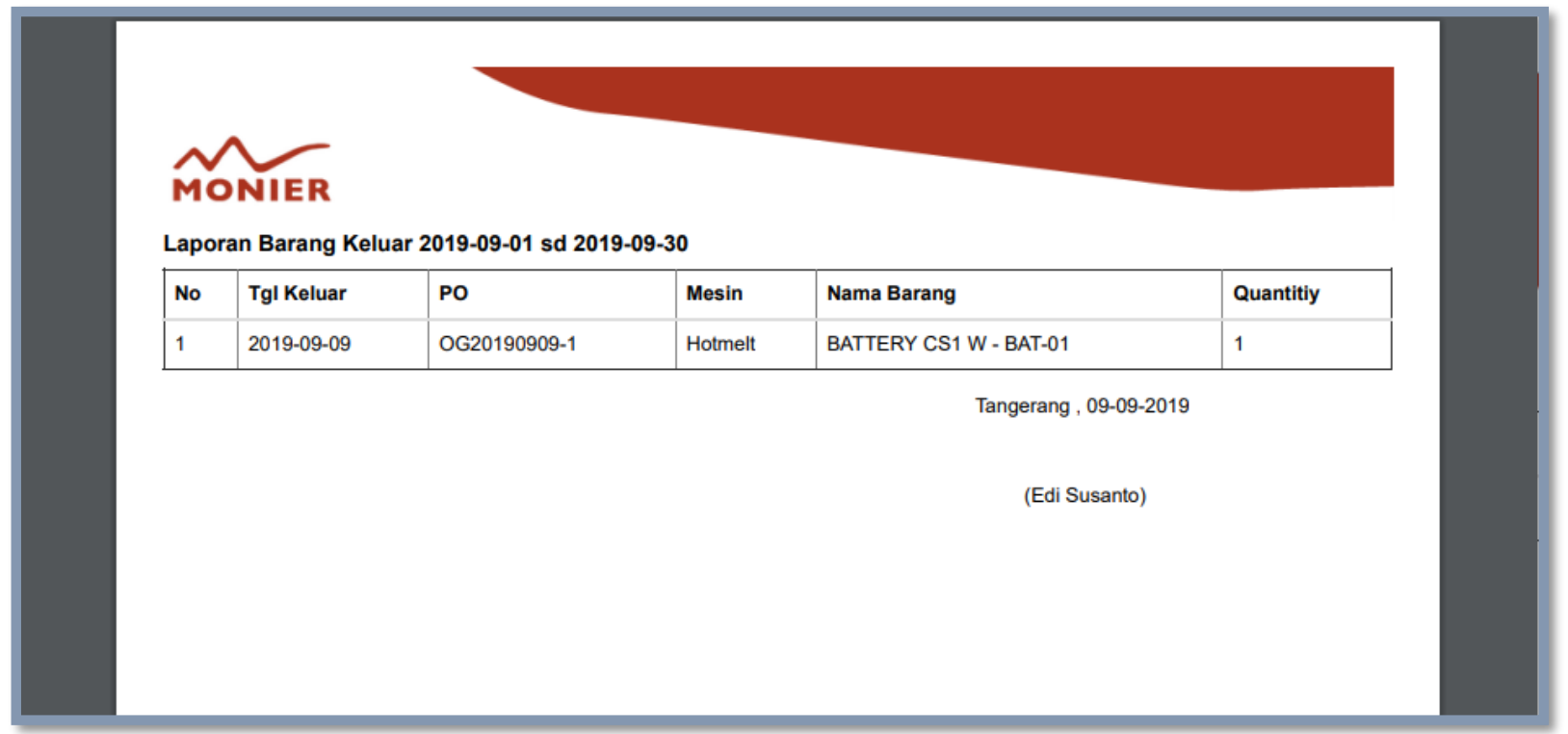

Figure 10. Display Outgoing Goods Report

Once the admin of the warehouse make goods transactions outgoing admin Warehouse can see the data reports out existing items every day, monthly and yearly. In the Data menu display of outgoing items on the system, this view of the warehouse admins can see in detail what there is on the exit item so as not to make a mistake in the number of items that are out there and make the data more accurate.

\section{Conclusion}

Based on the analysis that has been done and has been in accordance with what you want to be displayed, can be concluded by the existence of inventory stock system in PT. Monier can provide effective and efficient facilities because:

1. With the creation of a stock website inventory goods with good warehouse admins will be easier to input data at once in the manufacture of data reports of goods effectively and efficiently.

2. The supply of goods in PT Monier has not been well controlled, so that the warehouse part does not know directly the amount of stock of goods in the warehouse. This causes the difficulty of getting information updated about the overall stock report of the goods.

3. The draft information system of stock inventory in PT. Monier started from the creation of the UML diagram, then made a draft prototype with the application Balsamiq in order to be implemented in the form of web-based coding.

\section{References}

[1] Anthony, A., Tanaamah, A. R., \& Wijaya, A. F. (2017). Analisis Dan Perancangan Sistem Informasi Penjualan Berdasarkan Stok Gudang Berbasis Client Server (Studi Kasus Toko Grosir "Restu Anda"). Jurnal Teknologi Informasi dan Ilmu Komputer, 4(2), 136-147.

[2] Putra, M. R. (2018). ANALISA PERANCANGAN SISTEM INFORMASI PREDIKSI PEMESANAN DAN PENGENDALIAN STOK BARANG DENGAN MENGGUNAKAN METODE EOQ. TEKNOLOGI, 6(2).

[3] Fatmawati, F., \& Munajat, J. (2018). Implementasi Model Waterfall Pada Sistem Informasi Persediaan Barang Berbasis Web (Studi Kasus: PT. Pamindo Tiga T). MEDIA INFORMATIKA BUDIDARMA, 2(2). 
[4] Sari, A. O., \& Nuari, E. (2017). Rancang Bangun Sistem Informasi Persediaan Barang Berbasis Web dengan Metode Fast (framework For The Applications). Jurnal Pilar Nusa Mandiri, 13(2), 261-266.

[5] Kom, K. M. (2018). PERANCANGAN APLIKASI PENDATAAN SUPLAYER GETAH KARET PADA PT. RUBBER HOCK LIE MENGGUNAKAN VISUAL BASIC. NET. Jurnal IImiah INFOTEK, 3(1).

[6] Baramuli, F., \& Pangemanan, S. S. (2015). Analisis Sistem Informasi Akuntansi Persediaan Pada Yamaha Bima Motor Toli-Toli. Jurnal EMBA: Jurnal Riset Ekonomi, Manajemen, Bisnis dan Akuntansi, 3(3).

[7] Aris, A., Rinja, M., \& Jherico, T. (2017). Aplikasi Sistem Penjualan Sparepart Motor Pada Bengkel Barokah Motor Berbasis Web. Technomedia Journal, 2(1), 95-104.

[8] Haryanta, A., Rochman, A., \& Setyaningsih, A. (2017). Perancangan Sistem Informasi Perencanaan Dan Pengendalian Bahan Baku Pada Home Industri. Jurnal Sisfotek Global, 7(1). 